\title{
Sociobiology
}

RESEARCH ARTICLE - ANTS

\section{Mandibles of Leaf-Cutting Ants: Morphology Related to Food Preference}

\author{
LC SILVA ${ }^{1}$, RS CAMARGO ${ }^{1}$, JFS LOPES ${ }^{2}$, LCFORTI ${ }^{1}$ \\ 1 - Faculdade de Ciências Agronômicas/UNESP, Botucatu-SP, Brazil \\ 2 - Universidade Federal de Juiz de Fora, Juiz de Fora-MG, Brazil
}

\section{Article History}

\section{Edited by}

Evandro Nascimento Silva, UEFS, Brazil

Received 02 March 2016

Initial acceptance 19 June 2016

Final acceptance 11 September 2016

Publication date 25 October 2016

\section{Keywords}

Hymenoptera, Atta, Social insects, Leafcutting ants.

\section{Corresponding author}

Roberto da Silva Camargo

Laboratório de Insetos Sociais-Praga

Departamento de Produção Vegetal

Faculdade de Ciências Agronômicas/UNESP

Rua Dr. José Barbosa de Barros, 1780

CEP: 18610-307 - Botucatu-SP, Brasil

E-Mail: camargobotucatu@yahoo.com.br

\begin{abstract}
Feeding adaptation is crucial for the ecological success of animals, which explore specific or varied resources according to the suitability of the selected morphological feature. We hypothesized that the mandibles of leaf-cutting ants exhibit a specialization because of the specific food preference of some species. The objective of this study was to highlight possible morphological differences between the mandibles of leaf-cutting ant species of the genus Atta related to food preference, i.e., to investigate the morphofunctionality. A detailed description of the mandibles of workers of the grass-cutting ant Atta bisphaerica and of the leaf-cutting ant Atta sexdens rubropilosa was provided. For morphometric analysis, 50 individuals of four size classes were dissected for removal of the right mandible and one sample of each caste was processed for scanning electron microscopy. It was observed differences between species and among castes, demonstrating the clear specialization of workers. Although the results of mandibular morphometry accept the hypothesis of morphofunctionality, further investigation is needed taking into consideration the body size of foragers, robustness and factors that confer greater resistance to the mandibles such as zinc content, the force employed during cutting, and mandibular biomechanics.
\end{abstract}

\section{Introduction}

The mandibular morphology reflects the species' adaptations to particular foraging habits and social life (Gronenberg et al., 1997). Leaf-cutting ants (Atta and Acromyrmex), in particular, use different parts of plants for cultivation of their symbiotic fungus, with some species preferring dicotyledons and others grasses (monocotyledons) (Fernandez et al., 2015). Grass-cutting ants tend to have more massive and shorter mandibles, while the mandibles of leafcutting ants are longer and less massive (Fowler et al., 1986). Actually, comparing Atta species with these different plant preferences has demonstrated they had similar mandible morphology, primarily differing in distal tooth length, while Acromyrmex exhibited a higher variation in the mandible format as a whole (Camargo et al., 2015).

In general, the leaf blade of grasses contains abundant cells with lignified walls (Scheffer-Basso et al., 2002; Pelegrine et al., 2009), which renders them more resistant to cutting, as well as solid particles of hydrated silica $\left(\mathrm{SiO}_{2} \mathrm{nH}_{2} \mathrm{O}\right)$ found in the epidermal cells (Motomura et al., 2002). The accumulation of silicon has been associated with a variety of functions, including protection against fungal attacks, resistance to water loss, stimulation of photosynthesis, and structural support (Lux et al., 2003; Müller, 2003; Hattori et al., 2005). Moreover, silica plays an important role in the interaction between herbivores and plants. Massey et al. (2006a, 2006b, 2007, 2008, 2009) showed that silica accumulation in grasses increases leaf abrasiveness, causing the wear and deterioration of mandibles and impairing insect feeding.

In view of this previous knowledge, we hypothesized that the mandibular morphology of workers differs according to the plants preferentially cut by them. Therefore, this study compared the morphology of worker mandibles between castes (soldier, forager, generalist and gardener according to Wilson, 1980). It is expected that the mandible of grass- 
cutting ants is more massive and shorter, while the mandible of leaf-cutting ants would be longer and less massive.

\section{Material and methods}

Two leaf-cutting ant species, A. s. rubropilosa and A. bisphaerica, were used in this study. Field and laboratory colonies were used. For the collection of A. bisphaerica workers, a single fungus chamber of an adult nest was excavated on the Santana farm located near the Lageado Experimental Farm of UNESP, Botucatu, São Paulo, Brazil (geographic coordinates: $22^{\circ} 50^{\prime} 46^{\prime \prime} \mathrm{S}$ and $48^{\circ} 26^{\prime} 2^{\prime \prime} \mathrm{W}$ ). In this farm, the pasture was predominantly covered with Paspalum sp. with some patches of Brachiaria here and there. A. s. rubropilosa workers were obtained from an adult laboratory colony (10 years old, 50 liters of fungus garden). For morphometric analysis, 50 individuals of each caste were dissected for removal of the right mandible under a stereoscope: gardener (head width 0.8-1.2 mm; $\mathrm{n}=50$ ), generalist worker (head width 1.3-1.6 mm; $\mathrm{n}=50$ ), forager (head width 1.7-2.2 mm; $\mathrm{n}=50$ ), and soldier (head width $\geq 3.3$ $\mathrm{mm} ; \mathrm{n}=50$ ). This caste determination was proposed by Wilson $(1980,1983)$. The observations were made on the ventral side of right mandibles.

The following measurements were made using a micrometer eyepiece coupled to a stereomicroscope: 1) length of the mandible; 2) width of the mandible; 3 ) length of the first tooth; 4) length of the second tooth; 5) number of teeth and 6) head width (mm).

To detect morphological differences between mandibles of the different ant species, samples of the right mandible of workers of all size classes were fixed in $2.5 \%$ glutaraldehyde in $0.1 \mathrm{M}$ phosphate buffer, $\mathrm{pH} 7.3$, critical point dried, sputtered with gold (Robards, 1978), and examined by scanning electron microscopy (SEM) (FEI Quanta ${ }^{\mathrm{TM}} 200$ ) at the Center of Electron Microscopy, Institute of Biosciences (Centro de Microscopia Eletrônica do Instituto de Biociências-CME-IBB), UNESP, Botucatu, SP. For determination of the occurrence of wear, the mandible of an $A$. s. rubropilosa forager was collected 1 day after emergence and submitted to the same procedures for SEM analysis.
We analyzed the data and verified that all variables weren't normally distributed (Shapiro-Wilk normality test), being thus log-transformed. Principal Component Analysis (PCA) was used to examine variation in the morphometric data among species using the free software PC-ORD 5.15 (McCune $\&$ Mefford, 2011), with exception of the number of teeth. The number of principal components (PCs) was determined considering eigenvalues higher than those generated by the Brokenstick method. The morphometric measurements that most contributed to the axes, were selected by Pearson ( $r>$ 0.7). After that, we performed an ANOVA comparing the PCA scores with Tukey HSD post-test $(\alpha=0.05)$, to point out the differences among the variables.

\section{Results}

We found differences between species and among castes (ANOVA, $\mathrm{F}_{7,391}=455.2, \mathrm{P}<0.001$ ). All castes differed among them, except between soldiers from A. s. rubropilosa and $A$. bisphaerica $(\mathrm{P}=0.31)$ and $A$. bisphaerica generalist workers with $A$. s. rubropilosa foragers ( $\mathrm{P}=0.11$ ) (Table 2).

PCA analysis found that the first principal component explains $91.5 \%$ of the variation. Also it is strongly correlated with the four morphometric variables. The first principal component increases with decreasing length mandible ( $\mathrm{r}=$ $-0.96)$, width mandible $(\mathrm{r}=-0.96)$, length of the first teeth $(\mathrm{r}=$ $-0.98)$ and length of the second teeth $(\mathrm{r}=-0.93)$. This suggests that these four morphometric measures vary together. If one decreases, then the remaining also decreases. It would follow that species and castes would tend to be grouped due to their mandible features, in terms of the morphometric measurements (Figure 1).

Differences were also detected within the different castes of each species. Soldiers of the two species had larger and more robust mandibles compared to the other castes. Mandibular morphology of foragers although similar to that of soldiers, were smaller mandibles and with teeth more worn (Figure 6-7). The mean number of teeth was 7 or 8 for $A$. bisphaerica and 7 to 9 for A. s. rubropilosa (Table 1). Tooth

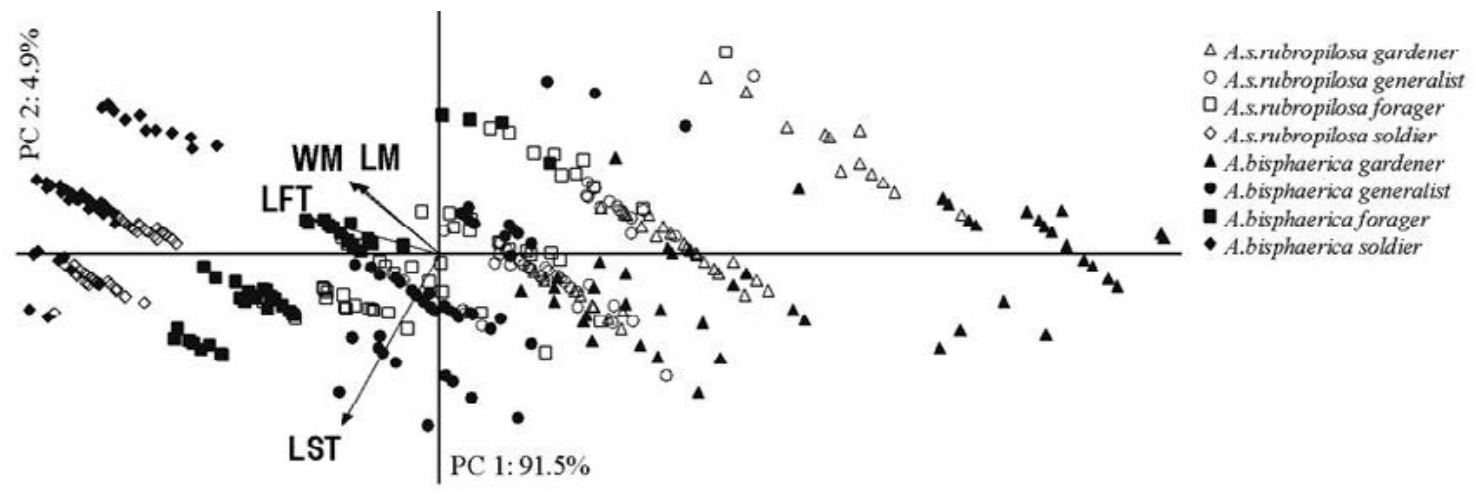

Fig 1. Principal components analysis of mandible morphometric data of Atta sexdensrubropilosa and Atta bisphaerica in each worker caste for the variables width mandible (WM), Length mandible (LM) Length of the fisrt tooth (LFT) and length of the second tooth (LST) First two principal components (PCs) are plotted with the proportion of variance explained by each component printed next to the axes labels. 
Table 1. Morphometric measures (mean and standard deviation) (mm) of the mandibles and teeth of Atta bisphaerica and Atta sexdens rubropilosa.

\begin{tabular}{llllllll}
\hline Ant species & Caste & Head width & $\begin{array}{l}\text { Mandibular } \\
\text { length }\end{array}$ & $\begin{array}{l}\text { Mandibular } \\
\text { width }\end{array}$ & $\begin{array}{l}\text { Length of } \text { st }^{\text {st }} \\
\text { tooth }\end{array}$ & $\begin{array}{l}\text { Length of 2n } \\
\text { tooth }\end{array}$ & $\begin{array}{l}\text { Number of } \\
\text { teeth }\end{array}$ \\
\hline \multirow{3}{*}{ Atta bisphaerica } & Gardener & $0.76 \pm 0.20$ & $0.40 \pm 0.10$ & $0.25 \pm 0.09$ & $0.08 \pm 0.06$ & $0.04 \pm 0.02$ & $10.14 \pm 2.12$ \\
& Generalist & $1.29 \pm 0.10$ & $0.67 \pm 0.06$ & $0.46 \pm 0.04$ & $0.20 \pm 0.04$ & $0.09 \pm 0.03$ & $7.92 \pm 0.73$ \\
& Forager & $2.13 \pm 0.19$ & $0.99 \pm 0.08$ & $0.70 \pm 0.06$ & $0.26 \pm 0.05$ & $0.13 \pm 0.04$ & $7.78 \pm 0.79$ \\
& Soldier & $4.79 \pm 0.43$ & $1.58 \pm 0.08$ & $1.11 \pm 0.07$ & $0.49 \pm 0.07$ & $0.14 \pm 0.03$ & $7.78 \pm 0.68$ \\
& Gardener & $0.89 \pm 0.13$ & $0.51 \pm 0.10$ & $0.30 \pm 0.06$ & $0.10 \pm 0.03$ & $0.05 \pm 0.02$ & $9.46 \pm 1.15$ \\
Atta sexdens & Generalist & $1.32 \pm 0.08$ & $0.65 \pm 0.06$ & $0.40 \pm 0.05$ & $0.13 \pm 0.03$ & $0.07 \pm 0.02$ & $8.84 \pm 1.08$ \\
& Forager & $2.02 \pm 0.18$ & $0.88 \pm 0.11$ & $0.52 \pm 0.07$ & $0.17 \pm 0.05$ & $0.09 \pm 0.03$ & $8.36 \pm 1.05$ \\
& Soldier & $3.79 \pm 0.23$ & $1.54 \pm 0.07$ & $0.94 \pm 0.05$ & $0.41 \pm 0.04$ & $0.17 \pm 0.03$ & $8.64 \pm 0.80$ \\
\hline
\end{tabular}

wear was observed when adult foragers of undetermined age (Figure 10) were compared with an adult on day 1 after hatching (Figure 11). As can be clearly seen in Figure 10, the teeth of probably older foragers were slightly rounder, probably due to wear out, when compared to the naive forager worker (1-day old) (Figure 11), in which a larger number of teeth and more pointed teeth can be seen.

Generalist workers of $A$. bisphaerica had more elongated mandibles when compared to A. s. rubropilosa (Figure 4-5) and presented no tooth wear. However, Figure 4 shows wear out of the mandible of generalists $A$. bisphaerica workers.

The elongated mandibles of $A$. bisphaerica were also observed in gardeners of this species (Figure 2-3). No tooth wear was observed in this caste of the both species. Gardeners had a larger number of teeth and more pointed teeth than the other castes analyzed (Table 1).

In all castes of the two species the teeth had a serrated appearance characterized by a progressive reduction in their size. The main difference between species was the larger size of the distal tooth in Atta bisphaerica.

These results demonstrate that the mandible morphology is different between species and within castes. However, a difference within castes seems to be found at the same features in both species.

\section{Discussion}

Leaf-cutting ants in general (Atta and Acromyrmex) use different parts of plants for cultivation of the symbiotic fungus. Some species prefer dicotyledons, while others prefer grasses (monocotyledons) (Fernandez et al., 2015), a fact raising the hypothesis of a greater degree of specialization in view of the specific food preferences of these species. The results of the present study accept the hypothesis of morphofunctionality of leaf-cutting ant (A. s. rubropilosa) and grass-cutting ant mandibles (A. bisphaerica) is related to food preference. This hypothesis was raised by Fowler et al. (1986) based on the morphological differences observed in these groups. In this respect, in species that preferentially cut grasses the foragers tend to have shorter mandibles compared to foragers of leaves
Table 2. Statistical summary of multiple comparison by Tukey HSD $(\alpha=0.05)$. SS: A. s. rubropilosa soldiers; FS: A. s. rubropilosa foragers; GS: A. s. rubropilosa generalist workers; GS: A. s. rubropilosa gardeners; SB: A. bisphaerica soldiers; FB: A. bisphaerica foragers; GB: Atta bisphaerica generalist workers; GB: A. bisphaerica gardeners.

\begin{tabular}{|c|c|c|c|c|}
\hline \multirow[b]{2}{*}{ Comparisons } & \multirow[b]{2}{*}{$\begin{array}{c}\text { Mean } \\
\text { difference }\end{array}$} & \multicolumn{2}{|c|}{ Confidence Intervals } & \multirow[b]{2}{*}{$\begin{array}{l}\mathrm{P} \text { - value } \\
\text { adjusted }\end{array}$} \\
\hline & & $\begin{array}{l}\text { Lower } \\
\text { Bound }\end{array}$ & $\begin{array}{l}\text { Upper } \\
\text { Bound }\end{array}$ & \\
\hline FS-JS & 0.606 & 0.491 & 0.720 & $<0.0001$ \\
\hline FS-SB & -0.756 & -0.870 & -0.641 & $<0.0001$ \\
\hline FS-SS & -0.670 & -0.785 & -0.555 & $<0.0001$ \\
\hline GS-GB & 0.173 & 0.058 & 0.288 & 0.0001 \\
\hline JB-GB & 0.742 & 0.627 & 0.857 & $<0.0001$ \\
\hline JS-GB & 0.502 & 0.386 & 0.617 & $<0.0001$ \\
\hline SB-GB & -0.860 & -0.975 & -0.745 & $<0.0001$ \\
\hline SS-GB & -0.774 & -0.889 & -0.659 & $<0.0001$ \\
\hline JB-GS & 0.569 & 0.454 & 0.684 & $<0.0001$ \\
\hline JS-GS & 0.328 & 0.214 & 0.443 & $<0.0001$ \\
\hline SB-GS & -1.033 & -1.148 & -0.918 & $<0.0001$ \\
\hline SS-GS & -0.947 & -1.062 & -0.833 & $<0.0001$ \\
\hline JS-JB & -0.240 & -0.355 & -0.125 & $<0.0001$ \\
\hline SB-JB & -1.603 & -1.717 & -1.488 & $<0.0001$ \\
\hline SS-JB & -1.517 & -1.632 & -1.402 & $<0.0001$ \\
\hline SB-JS & -1.362 & -1.477 & -1.247 & $<0.0001$ \\
\hline SS-JS & -1.276 & -1.391 & -1.162 & $<0.0001$ \\
\hline SS-SB & 0.085 & -0.029 & 0.200 & 0.3097 \\
\hline FS-FB & 0.253 & 0.139 & 0.368 & $<0.0001$ \\
\hline GB-FB & 0.357 & 0.242 & 0.473 & $<0.0001$ \\
\hline GS-FB & 0.531 & 0.416 & 0.645 & $<0.0001$ \\
\hline JB-FB & 1.100 & 0.985 & 1.215 & $<0.0001$ \\
\hline JS-FB & 0.859 & 0.745 & 0.974 & $<0.0001$ \\
\hline SB-FB & -0.502 & -0.617 & -0.387 & $<0.0001$ \\
\hline SS-FB & -0.416 & -0.531 & -0.302 & $<0.0001$ \\
\hline GB-FS & 0.104 & -0.011 & 0.219 & 0.1096 \\
\hline GS-FS & 0.277 & 0.162 & 0.392 & $<0.0001$ \\
\hline JB-FS & 0.846 & 0.732 & 0.961 & $<0.0001$ \\
\hline
\end{tabular}

*Significant difference at $95 \%$ family-wise confidence level by Tukey HSD test. 

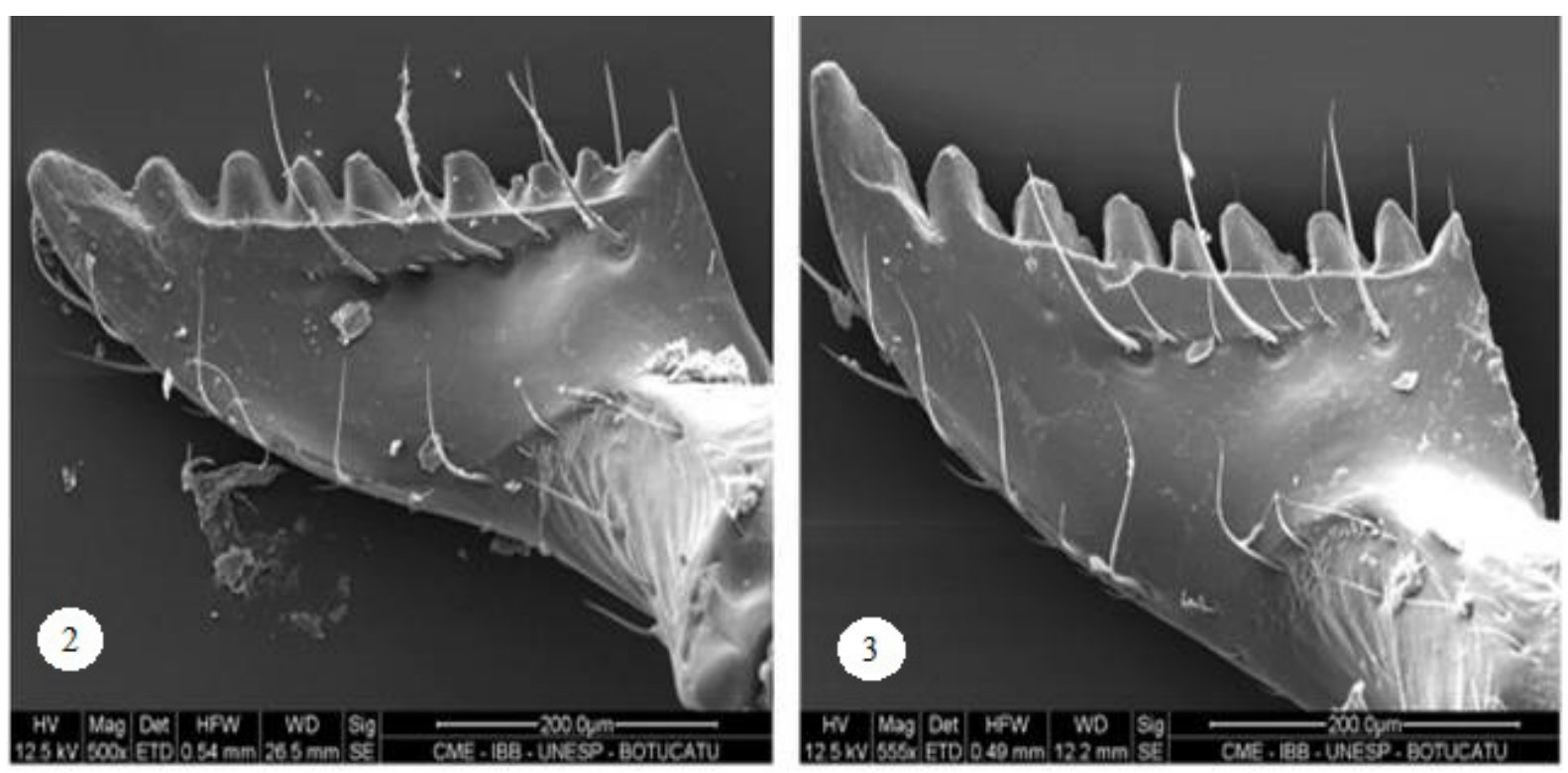

Figs 2-3. ventral side of right mandibles of Atta bisphaerica (2) and Atta sexdens rubropilosa (3) gardeners.
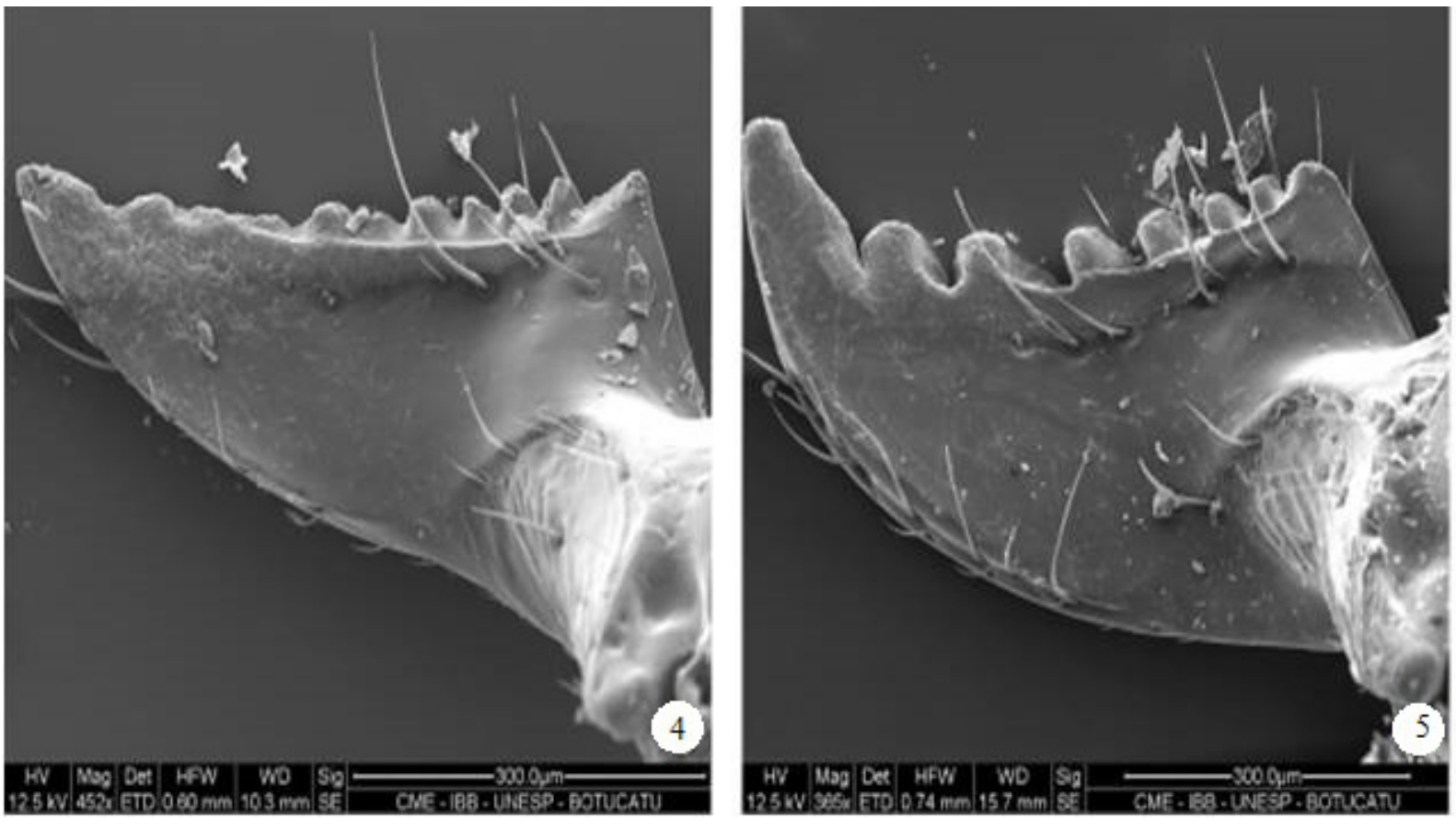

Figs 4-5. Ventral side of right mandibles of Atta bisphaerica (4) and Atta sexdens rubropilosa (5) generalist workers.

which tend to have less massive mandibles. As a consequence, these foragers cut plants differently. For example, during foraging Atta capiguara assumes a downward position while cutting the leaf blade of grasses, performing the cut and immediately returning to the nest. In contrast, in leaf-cutting ants the metathoracic legs serve as a pivot during cutting and their mandibles slide across the leaf blade. Behavioral differences between grass-cutting and leaf-cutting ants are also observed during cultivation of the symbiotic fungus (Lopes, 2004). Leaf-cutting ants exhibit a higher degree of processing of the foraged material that resembles grinding before incorporation of the symbiotic fungus. In contrast, in the case of grass-cutting ants the degree of processing is lower, i.e., the leaf blades are just arranged on the fungus garden and the symbiotic fungus is subsequently incorporated (Lopes, 2004). This behavior is probably related to the greater difficulty in processing the material due to the higher proportion of lignified tissues in grass leaves (Lopes, 2004).

In the present study, mandible morphometry was useful to discriminate between species and castes (Figure 1). These results are possibly related to the recent evolutionary history of the two species. The genus Atta is monophyletic (Bacci et al., 2009), with relatively recent adaptive radiation about 8 to 13 million years ago (Brady et al., 2006). However, the identification of adaptive radiation is based on the phylogenetic relationships of species and not on the dating of known fossils 
of Atta, which are scarce for the genus. There is only one trace fossil of an Atta nest from the Miocene located in Patagonia, Argentina (Laza, 1982).

This intimate phylogenetic relationship between the species studied (A. s. rubropilosa and A. bisphaerica) and their recent evolutionary history explain the morphological differences of the mandibles, at least in terms of the features evaluated (Table 1). These species are widely distributed in the Neotropical region and differ in nesting site, food preference and behavior. The grass-cutting ant $A$. bisphaerica is only found in Brazil (Wilson, 1986), particularly in the states of São Paulo, Minas Gerais, Rio de Janeiro and Mato Grosso do Sul (Forti \& Boaretto, 1997). In contrast, Atta sexdens and its subspecies are distributed from Costa Rica to Argentina and Paraguay (Wilson, 1986), with A. s. rubropilosa occurring in the midwestern and southeastern regions of Brazil (Forti \& Boaretto, 1997). The nesting site is a result of the biome. In this respect, $A$. bisphaerica nests are shallow and are generally found in open areas such as pastures characterized by a high incidence of insolation, while $A$. s. rubropilosa nests are relatively deep and are only found in shadow areas, such as native and eucalyptus forests (Forti et al., 2011).

Morphological differentiation between castes was observed in both species studied (Figures 2-3, 4-5, 6-7, 8-9, and 10-11) and was supported by the separation of species and grouping of the same castes by PCA analysis, using the mandible morphometric data. Gardeners are the smallest workers which are always found inside the nest and in larger quantities. The typical tasks attributed to this set of workers occur exclusively inside the nest, including brood care, final treatment of the substrate and hyphal inoculation into the fragments incorporated into the fungus garden (Wilson, 1983). Their mandibles are small in A. bisphaerica they are more elongated compared to the other castes since the tasks of gardeners are the most laborious and precise, with their teeth showing no wear (Figure 2-3). Generalist workers perform a relatively larger number of tasks that range from the elimination of residues from the colony and caring for the brood and queen to tasks related to cultivation of the symbiotic fungus (Wilson, 1983). The mandibles of $A$. bisphaerica generalists are visibly more elongated than those of $A$. s. rubropilosa, probably to facilitate the grass blades manipulation (Figure 4-5). Gardeners and generalists are the predominant size classes in the population of a leaf-cutting ant colony and are responsible for a large number of tasks related to preparation of the plant material during the process of incorporation (Peregrine \& Cherrett, 1974, 1976; Littledyke \& Cherrett, 1976). The elongated mandibular morphology observed only in A. bisphaerica gardeners and generalists might be related to the way grasses are processed. The leaf blades of grasses are not chopped or processed before incorporation as observed for dicotyledon leaf fragments which have a pulp-like appearance after processing by workers. According to Lopes et al. (2004), the latter processing facilitates the implantation of hyphal tufts.

On the other hand, the function of foragers is to explore, to excavate, to recruit other ants, and mainly to cut new plant material at field (Wilson, 1983), i.e., in both species studied these workers are not involved in the more laborious activities of plant processing, but rather in the exploration and cutting of plant material. As a consequence, the mandibles of these workers exhibited more marked tooth wear (Figure 6-7) reflecting the repetitive cutting effort. This assumption is mandibles of different age workers (Figure 10-11). Finally, the task attributed to soldiers is the defense of the nest (Wilson, 1983), an activity that requires larger and more robust mandibles (Figure 8-9) and is not related
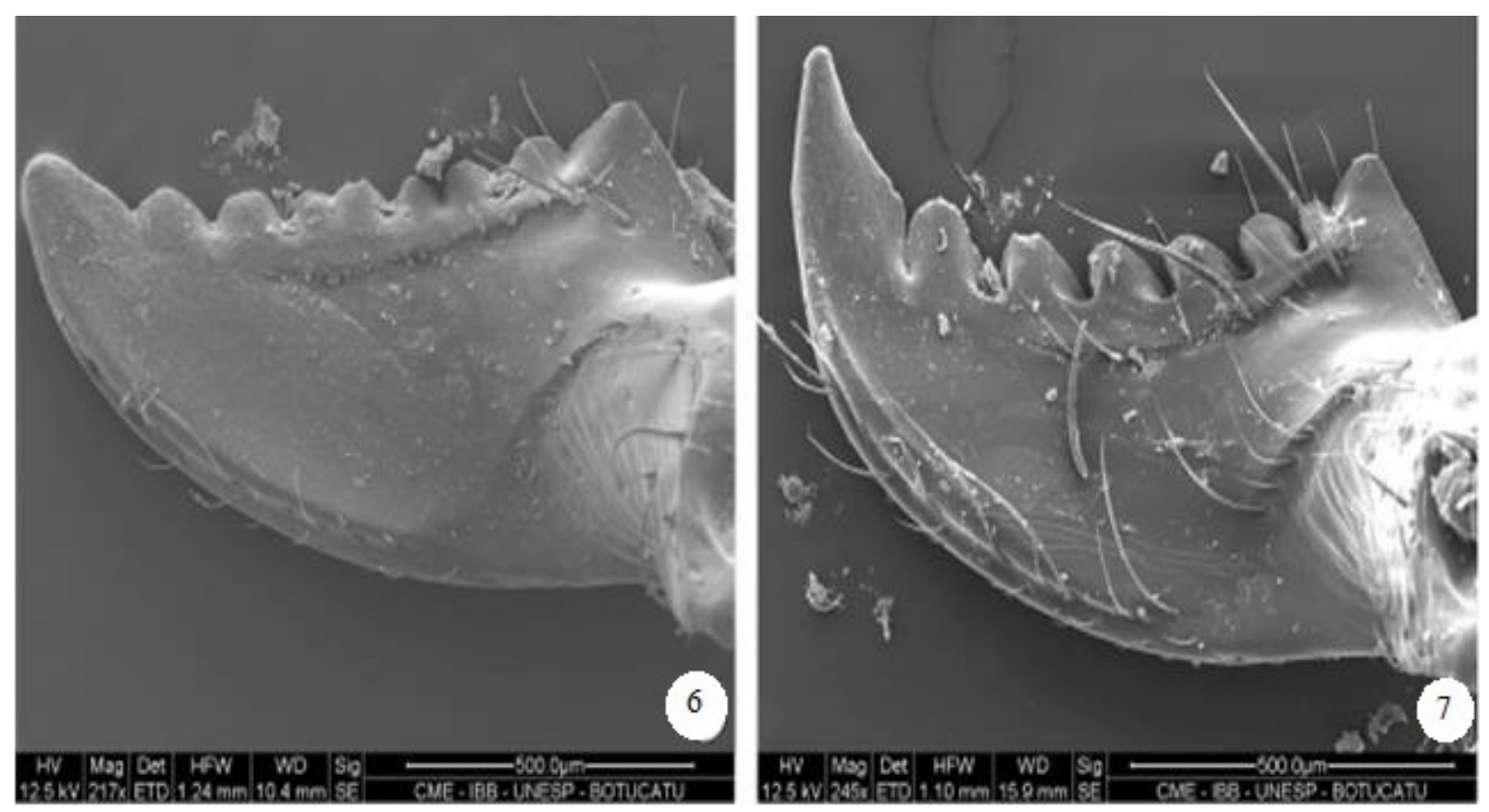

Figs 6-7. ventral side of right mandiblesof Atta bisphaerica (6) and Atta sexdensrubropilosa (7) foragers. 

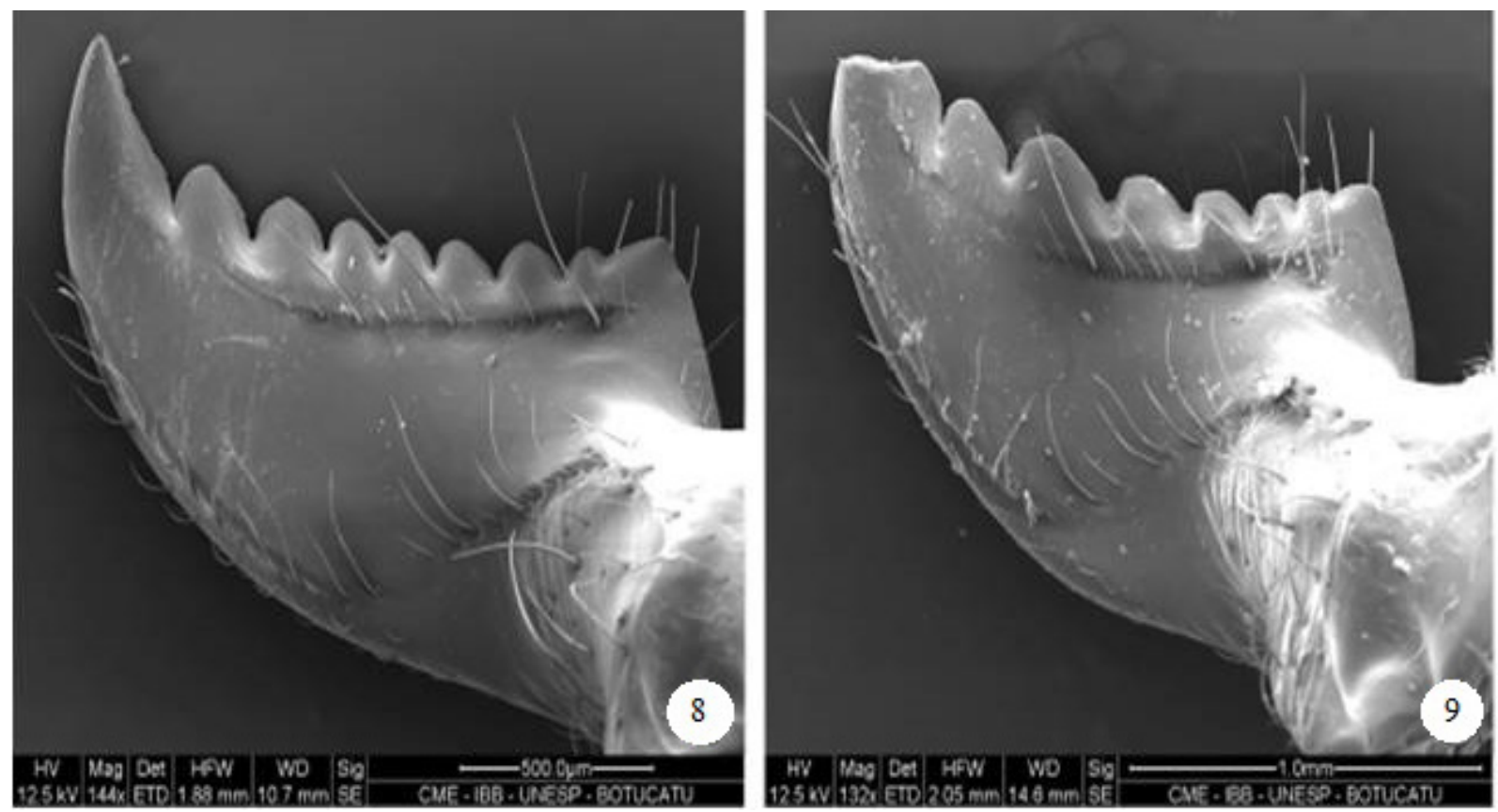

Figs 8-9. ventral side of right mandibles of Atta bisphaerica (8) and Atta sexdens rubropilosa (9) soldiers.
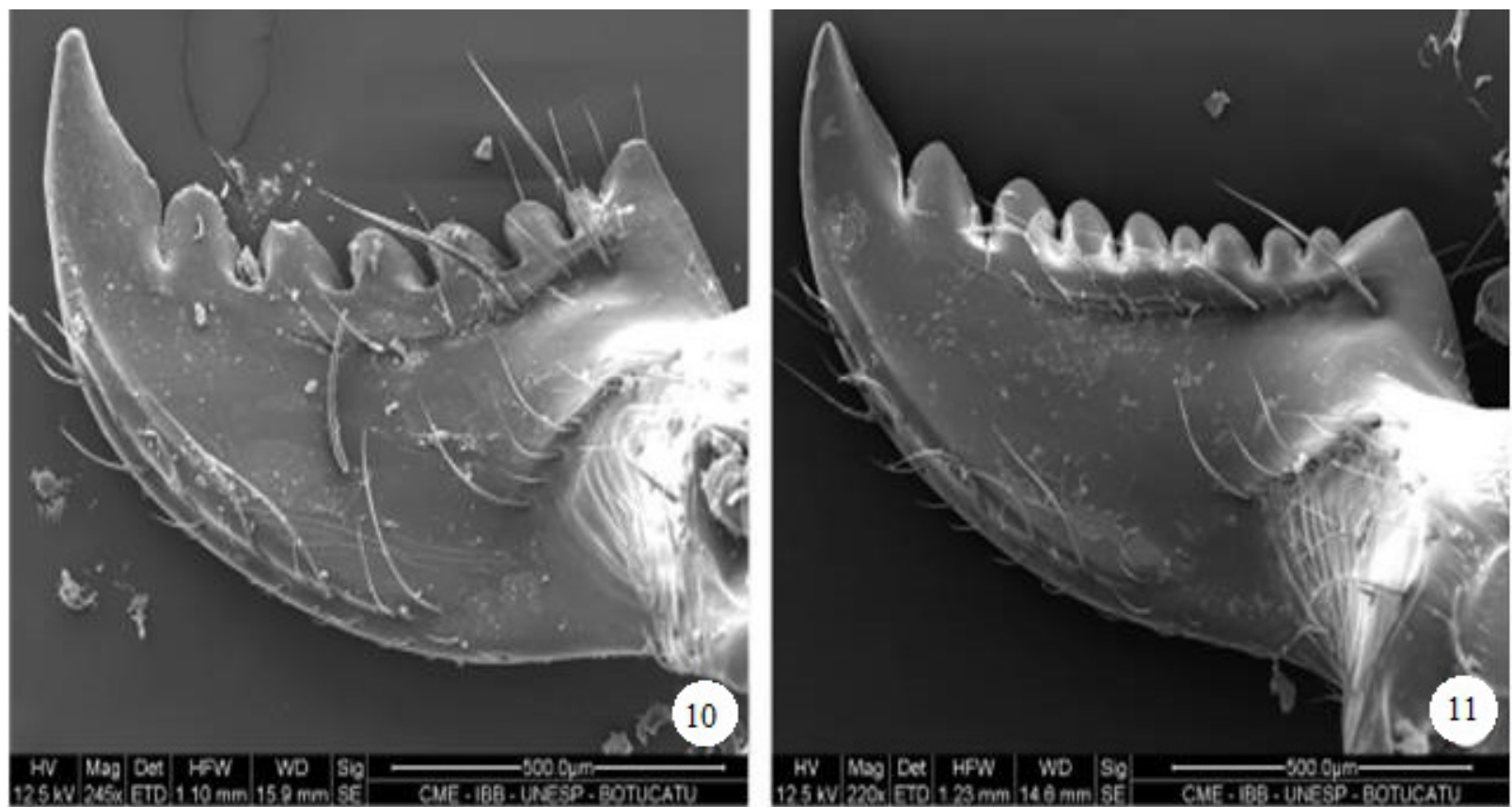

Figs 10-11. ventral side of right mandibles of Atta sexdens rubropilosa foragers at different ages, showing natural wear due to foraging activity. Adult of undetermined age (10) and adult one day after hatching (11).

with plant manipulation, explaining why soldier mandibles were not different between species. Like foragers, this group is not involved in the processing of plant material and no morphological differentiation between species is therefore observed. Also, A. bisphaerica generalist mandibles did not differ from A. s. rubropilosa forager mandibles suggesting that task allocation between species must be different. Actually, task allocation is different between species in function of which abilities the task require.

The mandibles of ants have many functions, such as catching prey, fight, cutting leaves, brood care, and commu- nication (Paul, 2001). Although an important tool for many tasks (Hölldobler \& Wilson, 1990), there is little information on the morphology of ant mandibles and no quantitative data regarding mandibular differences are available. The specialization of mandibles does not only depend on their morphology, but is also related to the velocity of movement and the force generated by them. For example, catching prey obviously requires movement characteristics that differ from those necessary for cracking seeds (Paul, 2001). Thus, the veins patterns of grasses and dicotyledons and the greater abundance of lignified cells in grasses should also influence the 
specialization of mandibles. Although the results of mandibular morphometry accept the hypothesis of morphofunctionality, further investigation is needed taking into consideration the body size of foragers, robustness and factors that confer greater resistance to the mandibles such as zinc content, the force employed during cutting, and mandibular biomechanics.

\section{Acknowledgements}

We are grateful to Fundação de Amparo à Pesquisa do Estado de São Paulo (FAPESP) for the financial support and stipends to the authors [grant numbers 2007/04010-0 and 2007/07091-0]. R.S. Camargo thanks Coordenação de Aperfeiçoamento de Pessoal de Nível Superior (CAPES) for the Postdoctoral fellowship. L.C. Forti thanks Conselho Nacional de Desenvolvimento Cientifico e Tecnológico for the research assistance (301917/2009-4). The authors are indebted to Dr. Rafael Barbieri for help with statistical analyses and helpful comments.

\section{References}

Andrade APP, Forti LC, Moreira AA (2002). Behavior of Atta sexdens rubropilosa (Hymenoptera: Formicidae) workers during the preparation of the leaf substrate for symbiont fungus culture. Sociobiology, 40: 293-306.

Bacci M, Solomon SE, Mueller UG (2009). Phylogeny of leafcutter ants in the genus Atta Fabricius (Formicidae: Attini) based on mitochondrial and nuclear DNA sequences. Molecular Phylogenetics and Evolution, 51: 427-437. doi: 10.1016/ j.ympev.2008.11.005

Brady SG, Schultz TR, Fisher BL (2006). Evaluating alternative hypotheses for the early evolution and diversification of ants. Proceeding of the National Academy of Sciences USA, 103: 18172-18177. doi: 10.1073/pnas.0605858103

Camargo RS, Forti LC, Lopes JF (2007). Age polyethism in the leaf-cutting ant Acromyrmex subterraneus brunneus Forel, 1911 (Hymenoptera: Formicidae). Journal of Applied Entomology, 131: 139-145. doi: 10.1111/j.1439-0418.2006. 01129.x

Camargo RS, Hastenreiter IN, Brugger M, Forti LC, Lopes JFS (2015) Relationship between mandible morphology and leaf preference in leaf-cutting ants (Hymenoptera: Formicidae). Revista Colombiana de Entomologia, 41: 241-244.

Correa PG, Pimentel RMM, Cortez JSA (2008). Herbivoria e anatomia foliar em plantas tropicais brasileiras. Ciência e Cultura, 60: 54-57.

Diniz E, Bueno OC (2009). Substrate preparation behaviors for the cultivation of the symbiotic fungus in leaf-cutting ants of the genus Atta (Hymenoptera: Formicidae). Sociobiology, 53: 651-666
Diniz EA, Bueno OC (2010). Evolution of substrate preparation behaviors for cultivation of symbiotic fungus in attine ants (Hymenoptera: Formicidae). Journal of Insect Behavior, 23: 205-214. doi: 10.1007/s10905-010-9207-y

Elliott CL, Snyder GH (1991). Autoclave-induced digestion for the colorimetric determination of silicon in rice straw. Journal of Agriculture and Food Chemistry, 39: 1118-1119. doi: $10.1021 / \mathrm{jf00006a024}$

Epstein E (1999). Silicon. Annual Review of Plant Physiology, 50:641-664. doi: 10.1146/annurev.arplant.50.1.641

Forti LC, Boaretto MAC (1997). Formigascortadeiras: biologia, ecologia, danos e controle. Botucatu: Departamento de Defesa Fitossanitária, Universidade Estadual Paulista, 61p.

Forti LC. Camargo RS, Matos CAO (2004). Aloetismo em Acromyrmex subterraneus brunneus Forel (Hymenoptera, Formicidae), durante o forrageamento, cultivo do jardim de fungo e devolução dos materiais forrageados. Revista Brasileira Entomologia 48: 59-63. doi: 10.1590/S008556262004000100011

Forti LC, Moreira AA, Andrade APP (2011). Nidificação e Arquitetura de Ninhos de Formigas-Cortadeiras. p.102-125, In: Della Lucia, T.M.C. Formigas-Cortadeiras da Bioecologia ao Manejo. Viçosa: Ed. UFV.

Fowler HG, Silva P, Forti LC (1986) Economics of grasscutting ants. In: Lofgren, C.S. \& Vander Meer, R.K. Fire ants and leaf-cutting ants: Biology and management. Westview Press, Boulder, 18-35p.

Fowler HG (1983). Distribution patterns of Paraguayan leafcutting ants (Atta and Acromyrmex) (Formicidae: Attini). Studies on Neotropical Fauna and Environment, 18: 121-138. doi 10.1080/01650528309360626

Hattori T, Inanaga S, Araki H (2005). Application of silicon enhanced drought tolerance in Sorghum bicolor. Physiological Plant, 123: 459-466. doi: 10.1111/j.1399-3054.2005.00481.x

Holldobler B, Wilson EO (1990). The Ants. Harvard University Press, Cambridge, 732p.

Laza JH (1982). Signos de actividad atribuibles a Atta (Myrmicidae, Hymenoptera) enel Mioceno de laprovincia de La Pampa, Republica Argentina. Ameghiniana, 19: 109-124.

Littledyke M, Cherrett JM (1976). Direct ingestion of plant sap from cut leaves by the leaf-cutting ant Atta cephalotes (L.) and Acromyrmex octospinosus (Reich) (Formicidae, Attini). Bulletin of Entomological Research, 66: 205-217. doi: 10.1017/ S0007485300006647

Lopes JFS, Forti LC, Camargo RS (2004). The influence of the scout upon the decision-making process of recruited workers in three Acromyrmex species (Formicidae: Attini). Behavioral Processes, 67: 471-476. doi10.1016/j.beproc.2004.08.001

Lopes JFS (2004). Diferenciação comportamental de espécies 
de Acromyrmex spp. (Mayr, 1865) (Hymenoptera, Formicidae) cortadeiras de monocotiledôneas e dicotiledôneas. Tese (Doutorado em Ciências Biológicas) - Botucatu-SP, Universidade Estadual Paulista, 93p.

Lux A, Luxová M, Abe J (2003). The dynamics of silicon deposition in the sorghum root endodermis. New Phytologist, 158: 437-441. doi: 10.1046/j.1469-8137.2003.00764.x

Massey FP, Ennos AR, Hartley SE (2006a). Silica in grasses as a defence against insect herbivores: contrasting effects on folivores and phloem feeder. Journal of Animal Ecology, 75: 595-603. doi: 10.1111/j.1365-2656.2006.01082.x

Massey FP, Hartley SE (2006b). Experimental demonstration of the anti-herbivore effects of silica in grasses: impacts on foliage digestibility and vole growth rates. Procedings of the Royal Society B. 273(1599): 2299-2304. doi: 10.1098/ rspb.2006.3586

Massey FP, Ennos R, Hartley SE (2007). Herbivore specific induction of silica-based plant defences. Oecologia, 152: 677683 doi: $10.1007 / \mathrm{s} 00442-007-0703-5$

Massey FP, Smith MJ, Lambin X (2008). Are silica defences in grasses driving vole population cycles? Biology Letters, 4 : 419-422. doi: 10.1098/rsbl.2008.0106.

Massey FP, Hartley SE (2009). Physical defences wear you down: progressive and irreversible impacts of silica on insect herbivores. Journal of Animal Ecology, 78: 281-291. doi: 10.1111/j.1365-2656.2008.01472.x

Motomura H, Mita N, Suzuki M (2002). Silica accumulation in long-lived leaves of Sasaveitchii (Carriere) Rehder (PoaceaeBambusoideae). Annals of Botany, 90:149-152. doi: 10.10 93/ aob/mcf148

McNaughton SJ, Tarrants JL (1983). Grass leaf silicification natural selection for an inducible defense against herbivores. PNAS, 80:790-791. doi:10.1073/pnas.0808075106

McCune B, Mefford MJ (2011). PC-ORD. Multivariate analysis of ecological data. Version 6.MjM Software, Gleneden Beach, Oregon, U.S.A.
Müller WEG (2003). Silicon biomineralization: biology, biochemistry, molecular biology, biotechnology. Berlin, Springer.

Peregrine DJ, Cherrett JM (1974). A field comparison of the modes of action of aldrin and mirex for controlling colonies of the leaf-cutting ants Atta cephalotes (L.) and Acromyrmex octospinosus (Reich) (Formicidae, Attini). Bulletin of Entomological Research, 63: 609-613. doi: 10.1017/S000 7485300047842

Peregrine DJ, Cherrett JM (1976). Toxicant spread in laboratory colonies of the leaf-cutting ant. Annals of Applied Biology, 84: 609-618. doi: 10.1111/j.1744-7348.1976.tb01742.x

Paul J (2001). Mandibles moviments in ants. Comparative Biochemistry and Physiology, 131: 7-20. doi: 10.1016/ S1095-6433(01)00458-5

Peeters PJ (2002). Correlations between leaf structural traits and the densities of herbivorous insect guilds. Biological Journal of the Linnean Society, 77: 43-65. doi: 10.1046/j.10958312.2002.00091.x

Schofield RM, Nesson MH, Richardson KA. (2002) Tooth hardness increases with zinc-content in the mandibles of young adult leaf-cutter ants. Naturwissenschaften, 89: 579-83. doi: 10.1007/s00114-002-0381-4

Vicari M, Bazely DR (1993). Do grasses fight back the case for antiherbivoredefenses. Trends in Ecology and Evolution, 8: 137-141. doi: 10.1016/0169-5347(93)90026-L.

Weber NA (1956). Treatment of substrate by fungus-growing ants. Anatomic Records, 125: 604-605.

Wilson EO (1980). Caste and division of labor in leaf-cutter ants (Hymenoptera, Formicidae). I: The overall pattern in $A$. sexdens. Behavioral Ecology and Sociobiology, 7: 143-156. doi: 10.1007/BF00299521

Wilson EO (1983). Caste and division of labor in leaf-cutter ants (Hymenoptera, Formicidae: Atta). IV: Colony ontogeny of A. cephalotes. Behavioral Ecology and Sociobiology, 14: 5560. doi: 10.1007/BF00366656 